\title{
Performance Management Methods: A Case Study from International Industrial Companies
}

\author{
Bogdan Kuzmanovic, Zdravko Tesic, Ivana Tomic, Sonja Buncic, Milos Tomic, Mirjana Sujic \\ Stamenic
}

University of Novi Sad

Trg Dositeja Obradovica 621000 Novi Sad, Republic of Serbia

E-mail.kbogdan@uns.ac.rs, ztesic@uns.ac.rs, ivanatomic159@gmail.com, pbsb@eunet.rs, milostomic2@gmail.com, mirjanasujic@yahoo.com

cross $^{\text {ref }}$ http://dx.doi.org/10.5755/j01.ee.30.1.16264

In the period of globalization, the management of international industrial companies has a problem of managing the production performance in different countries. In addition, there is a problem of creating business strategies and organizing effective and efficient production with the lowest costs because there are many indicators that may have impact on production and should be analysed in the decision-making process. The main objective of the research is creation and presentation of new methods for monitoring and analyzing KPIs suitable for displaying a combination of input, process and output measures, which implies the evaluation values of Key Performance Indicators (KPIs) according to their impact on international industrial companies' goals. This study presents a new model for performance analysis based on four main perspectives of international industrial companies. The model is presented using different methods, which include Tool for Action Plan Selection - TAPS, Analytic Hierarchy Process (AHP), Non-parametric Statistical Analysis with Kruskal-Wallis Test and a new method created in Lab View software. The methods are suitable for defining, analysing and visualization of KPIs and their impact on the company performance. Empirical part of the study is conducted in twenty international companies and research is based on assessing defined KPIs by General Management and Sector Managers. The research has largely achieved the objectives which determine that measuring of KPIs has a value for international industrial companies and can influence strategy development and help in organizing efficient production with minimum cost.

Keywords: Management; Measurement; Performance; Method; International Industrial Companies.

\section{Introduction}

Performance could be defined as the ability of an organization to achieve its goals (Stainer, 2006; Tomic et al., 2018). Management of international companies has a challenge that relates to strategies, synergy and integration of company parts in order to achieve the set goals (Spitzer, 2007; Milosev \& Tesic, 2011; Tesic et al., 2014). In the modern business environment companies have to be flexible enough to adapt quickly to market changes (Hammer \& Champy, 1993; Tesic et al., 2016) and analyze Key Performance Indicators (KPIs) as variables that, observed together, provide a general picture of the organizational performance and its processes (Kaplan \& Norton, 1996; Tomic et al., 2018). Briefly, KPIs are a set of measures focused on those aspects of the organizational performance that are the most critical for the current and future company success (Parmenter, 2007; Tomic et al., 2018). The need for research is primarily related to the need for defining KPIs and their impact on the achievement defined objectives of international industrial companies, which have a common goal that represents organizing the effective and efficient production with the lowest costs.

The research will present an innovative method for performance measuring and managing, designed as a tool that helps management in analyzing defined KPIs on the way that gives results suitable for performance measurement and decision-making.
Novelty and specific contribution of this research include the new model based on analysing company performance within four main perspectives with defined KPIs and new methods for KPIs analysis using different software tools which were not used for this kind of analysis before.

This study examines using software tools for performance measuring, testing predictions of general management compared with results from sector managers and support to managers in decision-making. The new developed software provides collection, processing and analysis of KPIs, as well as graphical presentation of their influence on the company performance (Tomic et al., 2018).

The aim of the research topic is creation and presentation of new methods for monitoring and analyzing KPIs that represent the necessary segments of the management of international industrial companies including methods for calculating useful results based on this analysis. Research problems relate to the ability of defining the most influential KPIs and creating new model for their analysis through four perspectives with the aim of obtaining results on the most influential KPIs using different software and tools which constitute one innovative method.

Scientific problem is defining the KPIs of an industrial company and analyzing their impact on the performance and decision-making, as well as the ability to apply KPIs impact analysis using appropriate methods in making managerial decisions. This analysis includes KPIs that are 
non-financial parameters since the financial parameters mainly relate to results from the previous period and give little information about expectations regarding the future company performance.

The aim of the article relates to the creation and presentation of new methods for monitoring and analyzing KPIs with the goal of contributing to easier management of the global industrial companies' performance. The article contains defining KPIs and various methods for calculations based on the results obtained by the survey, providing final results for strategic decision-making with suggestions for giving greater importance to cost reduction.

The main goal of the research is to measure the output size of the system in order to influence the input size, which in this research implies evaluating the value of KPIs in accordance with their impact on the goal of an industrial company, on the basis of which business strategies are defined, as well as the presentation of KPIs analysis using the new method within four perspectives.

The results expected from the survey include knowledge about the most influential performance indicators within each of the four defined areas of action within the industrial company to achieve its goal. Based on the results obtained with regard to the impact of KPIs and analysis with the help of defined approaches and programs, results are expected to give suggestions for strategic decisions.

\section{Theoretical Background}

Performance measuring can be defined as the process of quantifying the effectiveness and efficiency of actions (De Lima et al., 2009; Neely et al., 2005). Performance management is a continuous process of identifying, measuring and developing performance, as well as the harmonization of performance with the strategic goals of the organization (Aguinis \& Pierce, 2008).

Some scientists in defining the performance criteria focus on internal organizational factors, such as organizational objectives and procedures for achieving these goals (Selden \& Sowa, 2004; Tomic et al., 2018). Hong et al. (2011) indicate that in the management it is extremely important to analyse how the activities carried out in the organization have an impact on business performance. Chaudhuri et al. (2016) proposed a new model for performance assessing and De Toni \& Tonchia (2001) consider that there are four types of performance indicators and they include cost / productivity, time, flexibility and quality, with which it also defines the production strategy of industrial companies. Strategy and management systems have a significant impact on the industrial companies performance (Tsamenyi et al., 2011), and performance measurement provides reliable information that assist in decision creation (Ukko et al., 2007). Muchiri et al. (2011) suggest that performance measuring is a fundamental principle of management due to the fact that performance measures provide an important link between strategy and management activities. An essential condition for the fulfillment of the objectives is the proper selection of key indicators for assessing the production performance (Lohman et al., 2004; Tomic et al., 2018). Kennerley and Neely (2002) consider that there are numerous processes developed that can help managers in industrial companies to define a set of measures that reflect their objectives and evaluate their performance appropriately. Business process analysis is a term that is used in a broad sense, which also includes the analysis of business process performance, with KPIs as measurable factors for assessing the business processes results (Vergidis et al., 2008; Tomic et al., 2018). Ittner et al. (2003) point out that industrial companies with performance measuring easier access to the necessary information for identifying strategies and coordinate management processes such as goal setting, decision making and of performance evaluation. KPIs are used for performance measurement and management for analysing critical success factors and providing a link between strategy and activities (Hynuk \& Benoit, 2010; Muchiri et al., 2011). Gunday et al. (2011) believe that the desire of industrial companies to increase business efficiency and competitive advantage is the key reason for improving their performance (Tomic et al., 2018).

In the last two decades, academics and researchers in practice have developed performance measurement systems (PMS) including financial and non-financial measures (Ittner et al., 2003b; Martinez \& Kennerley, 2005; Neely at al., 2000), the prism (Neely, 2002) and the balanced scorecard (Kaplan \& Norton, 1992). Tan and Platt (2002) developed a tool for action plan selection (TAPS) with the aim to find the input variables required in order to achieve a given combination of output variable requirements and enable managers to build an input/process/output performance model. TAPS and AHP tools which help managers in analysing KPIs and creating strategic decisions will be presented in this research. With the aim of developing performance measures, organizational activities are grouped into five clusters: inputs, activities, outputs, outcomes and impacts (Epstein \& McFarlan, 2011). Bourne et al. (2000) suggest dividing the process of developing a system for measuring performance into three main phases that include performance measurement plan, implementing performance measurement and using the performance measurement (Tomic et al., 2018).

This research contributes to the literature on the way that presents new model for performance management based on assessing KPIs and their analysis on the new way using different software tools.

\section{Objectives and Hypotheses}

Research objectives can be defined as follows:

Objective 1: The findings about KPIs useful for creating strategies for industrial companies and reaching the knowledge of values of defined KPIs.

Objective 2: Acquiring the information necessary for organizing efficient production with minimum costs.

Objective 3: Development of a new model for measuring the impact of defined KPIs on the effectiveness, efficiency, cost reduction and performance of companies in the four functional areas using appropriate software tools in management decision-making, where the KPIs are nonfinancial parameters.

Hypotheses in accordance with the aim of the research can be defined as follows (Tomic et al., 2018):

Hypothesis 1: It is possible to set goals in an international industrial company in a way that will ensure better management decisions and create a model for assessing quantities of critical factors that influence on these goals.

Hypothesis 2: Relations and values of output variables can be defined based on the set parameters and it can be used in international industrial company. 
Hypothesis 3: It is possible to create a software solution for analysis defined KPIs, which includes their importance and value for the cost reduction, efficiency, effectiveness and the performance of defined period of time with calculation of mean values and graphs.

Since performance of international industrial companies could be more precisely analysed, it can be divided into four main areas that can be considered as the highest level process:

1. Marketing and Sales;

2. Logistics and Manufacturing;

3. Finance and Accounting;

4. Human Resources.

Within these four areas KPIs can be defined and the impact of each of these indicators can be determined on the achievement of industrial companies' goal which also has an impact in defining business strategies in the global market.

\section{Research Methodology}

The research will be conducted with the creation of the model based on input-process-output-outcome model (Spitzer, 2007) which will be analysed by creating the proposed method based on Connectance Model (Burbidge, $1984 \mathrm{a}, \mathrm{b}$ ) where the new model includes defining goal, four functional areas, sixty KPIs, conducting a survey based on Likert-type, statistical analysis, data processing in programs TAPS and AHP as well as development of new method for KPIs analysis in software Lab View. The new method includes sixty KPIs and the survey is based on the evaluation of the importance and value for each month, so the program calculates mean values for one year for each sector, as well as the average of the results from four sectors for each KPI, and then presents the results with graphic display for sectors and the whole company.

Non-parametric statistical analysis will be used for testing predictions of General Management compared with results as average scores from Sector managers. Calculations for this comparison will be made by implementing Kruskal-Wallis test. The performance analysis will be made within twenty international industrial companies operating in the Republic of Serbia, in different branches of industry including manufacturing and services. Data collection was conducted by interviewing senior and middle management of twenty international industrial companies as a representative sample. The survey is based on assessing defined KPIs in relation to their impact on company goal. The sample includes international companies which are selected as companies which analyse all defined KPIs for their strategies and operate within the various branches as Pharmaceutical, Automotive, Ceramic Production, Oil and Gas Industry, Cosmetics Production, Production of Household Appliances, Conductors Production and Port of Novi Sad.

KPIs were anaysed by many authors (Gunday et al., 2011; Koller et al., 2005; Koo \& Koo, 2007; Tan \& Platts, 2004) and in this research within four areas can be defined sixty KPIs (as it is shown in Table 1) and determined the influence of each indicator to achieving the goal of international industrial companies:

Sixty KPIs within Four Areas

\begin{tabular}{|c|c|}
\hline $\begin{array}{l}\text { KPIs in Marketing and Sales (11) } \\
\text { The share of sell orders executed at the time (111) } \\
\text { Customer satisfaction index (112) } \\
\text { Index of number of new customers during the period (113) } \\
\text { The index of quality of sold products (114) } \\
\text { Index of realization of contacts with customers (115) } \\
\text { Time from investment to cash collection (116) } \\
\text { Company's reputation on the market (117) } \\
\text { Reducing the number of customers (clients) (118) } \\
\text { The attractiveness of products to potential customers (119) } \\
\text { Recognition of the company's brands on the market (1110) } \\
\text { Percentage of saved customers in the last } 3 \text { years (1111) } \\
\text { Image of the company on the market (1112) } \\
\text { Customers loyalty to the company (1113) } \\
\text { The growth of the total number of customers (users) (1114) } \\
\text { The growth of the market share of the company (1115) }\end{array}$ & $\begin{array}{l}\text { KPIs in Logistics and Manufacturing (12) } \\
\text { Ratio of realized orders and deliveries (121) } \\
\text { Scarp rate (122) } \\
\text { Overall efficiency of technological systems (123) } \\
\text { Preparatory - final time (124) } \\
\text { Quality of transport (125) } \\
\text { Low transport costs (126) } \\
\text { Defects per million opportunities (127) } \\
\text { The percentage of damaged goods after delivery (128) } \\
\text { Reliability of logistical support (129) } \\
\text { Mean time between failures (1210) } \\
\text { The time required for inventory turnover (1211) } \\
\text { The overall efficiency of equipment (1212) } \\
\text { Average costs of production items (1213) } \\
\text { Reduction of costs of new product development (1214) } \\
\text { Reduction of imported materials (1215) }\end{array}$ \\
\hline $\begin{array}{l}\qquad \text { KPIs in Finance and Accounting (13) } \\
\text { Return on investment (131) } \\
\text { Inventory turnover ratio (132) } \\
\text { Turnover ratio of total assets (133) } \\
\text { Profit per product (134) } \\
\text { Net income (135) } \\
\text { Low salaries (136) } \\
\text { Low level of investment (137) } \\
\text { Liquidity index (138) } \\
\text { Return on equity (139) } \\
\text { Revenue per employee (1310) } \\
\text { Return on investment time (1311) } \\
\text { Profit per unit (1312) } \\
\text { Income taxes (1313) } \\
\text { The average salary per employee (1314) } \\
\text { Earning per project (1315) }\end{array}$ & $\begin{array}{l}\text { KPIs in Human Resources (14) } \\
\text { The efficiency of employees (141) } \\
\text { Professional expertise of employees (142) } \\
\text { Motivation of employees (143) } \\
\text { An effective business collaboration within the company (144) } \\
\text { Intellectual capital (145) } \\
\text { Innovations from the employees (146) } \\
\text { Education of employees (147) } \\
\text { Know- how (148) } \\
\text { Corporate culture (149) } \\
\text { Competent external partners (1410) } \\
\text { Average employees professional experience of the (1411) } \\
\text { Patents and licenses (1412) } \\
\text { Design rights (1413) } \\
\text { Entrepreneurial employees (1414) } \\
\text { Professional qualifications of employees (1415) }\end{array}$ \\
\hline
\end{tabular}




\section{Research Findings}

TAPS program. TAPS program performs modeling outputs, whereby the measurement of performance will be shown in four core areas of international industrial companies in which KPIs shall be defined based on assessing their impact by survey of industrial companies management, while the AHP program performs output performance score. Research was conducted in twenty international industrial companies on the basis of a questionnaire to senior management that analyzed the overall possibilities for efficient production with minimum cost (1) and middle managers in four sectors:
Marketing and Sales (11), Logistics and Manufacturing (12), Finance and Accounting (13) and Human Resources (14). Since the research is too large, the results of the survey will be described only for individual companies in TAPS and AHP methods within graphical images. Second company is chosen as an example for TAPS and first company as an example for AHP. The chosen companies are the best examples for mentioned methods within twenty analyzed companies which all have different results.

The results of the survey for the second company, worked in TAPS, are shown in Figure 1.

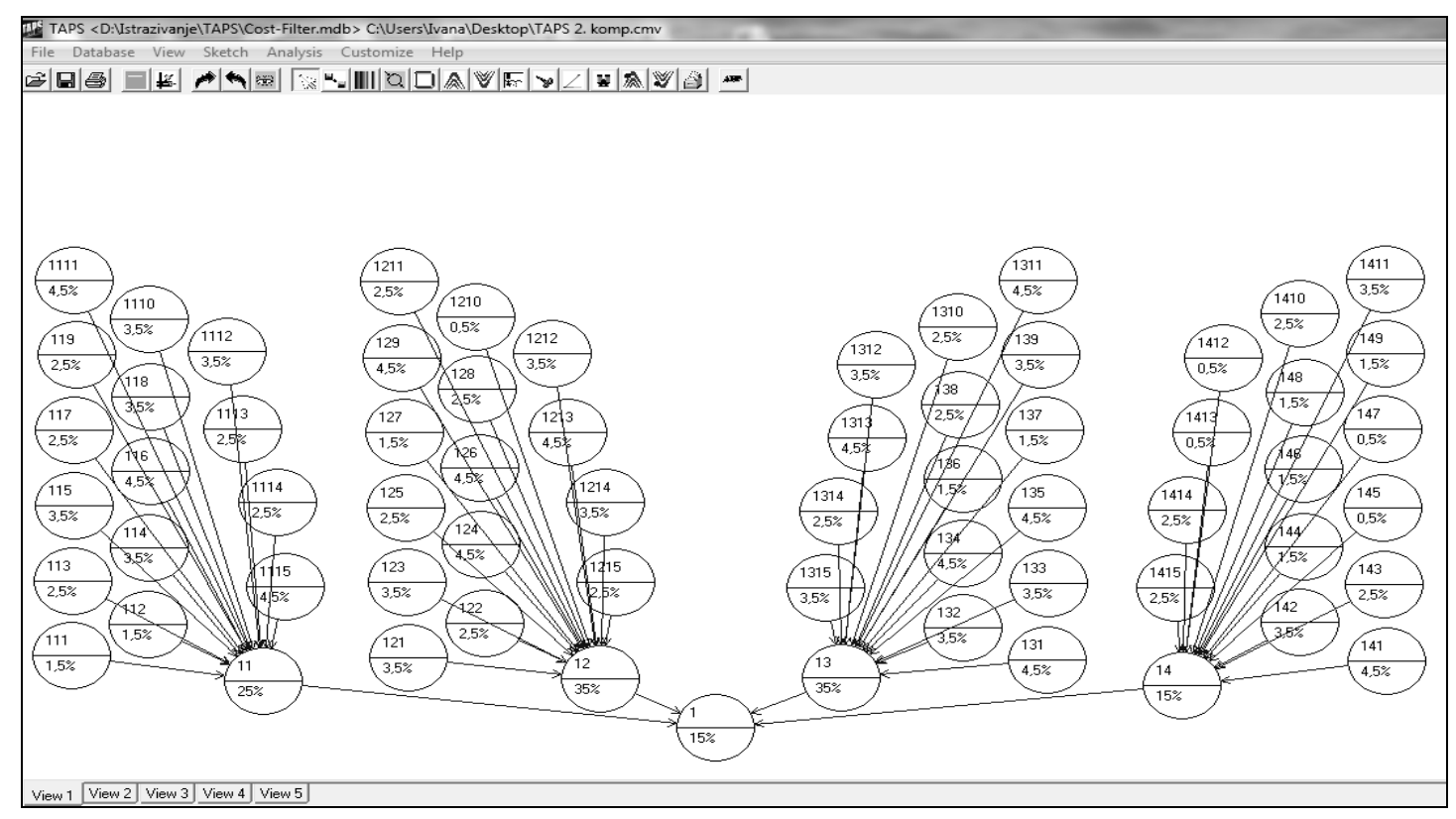

Figure 1. KPIs Presented in the TAPS Program for the Second Industrial Company

In Table 2 there are four sectors and the most influential KPIs within each sector.

Sixty KPIs within Four Areas

\begin{tabular}{|c|c|c|c|c|c|c|c|c|c|}
\hline IC & $\mathbf{1}$ & $\mathbf{1 1}$ & $\mathbf{1 2}$ & $\mathbf{1 3}$ & $\mathbf{1 4}$ & $\begin{array}{c}\mathbf{1 1 6 , 1 1 1 1} \\
\mathbf{1 1 1 5}\end{array}$ & $\begin{array}{c}\mathbf{1 2 4 , 1 2 6 ,} \\
\mathbf{1 2 9 , 1 2 1 3}\end{array}$ & $\begin{array}{c}\mathbf{1 3 1 , 1 3 4 , 1 3 5 ,} \\
\mathbf{1 3 1 1 , 1 3 1 3}\end{array}$ & \begin{tabular}{c}
$\mathbf{1 4 1}$ \\
\hline 2
\end{tabular} \\
\hline
\end{tabular}

In the second industrial company the most influential KPIs belong to sectors 12 and 13 , and their impact is 0.0023625. The most influential are the following KPIs with value 4,5\% and affiliation to sectors 12 and 13: 124 Preparatory - final time, 126 - Low transport costs, 129 Reliability of logistical support, 1213 - Average costs of production items, 131 - Return on investment, 134 - Profit per product, 135 - Net income, 1311 - Return on investment time, 1313 - Income taxes. On the same way, the analysis of defined four sectors are made in twenty analysed companies, and the total results indicate that the greatest impact on efficient production with minimum costs have Overall efficiency of technological systems (123) and Low transport costs (126).

\section{AHP Program}

Measurement of the Action Plan assesses AHP analysis, which defines the objectives, criteria and alternatives, and then comes to choosing the best alternative. AHP method helps managers to organise their decision-making processes and provides them with the ability to visualize their problem in the form of a hierarchical tree and see results of their evaluation in each stage of the process analysis (Tan \& Platts, 2004).

Based on the results of the questionnaires relating to the assessment of KPIs, it is possible to define alternatives in AHP program and analyse which alternative is the most important. An example refers to analysis of the first industrial company where the survey was conducted in four sectors and the analysis of Logistics and Manufacturing will be shown in Figure 2. 


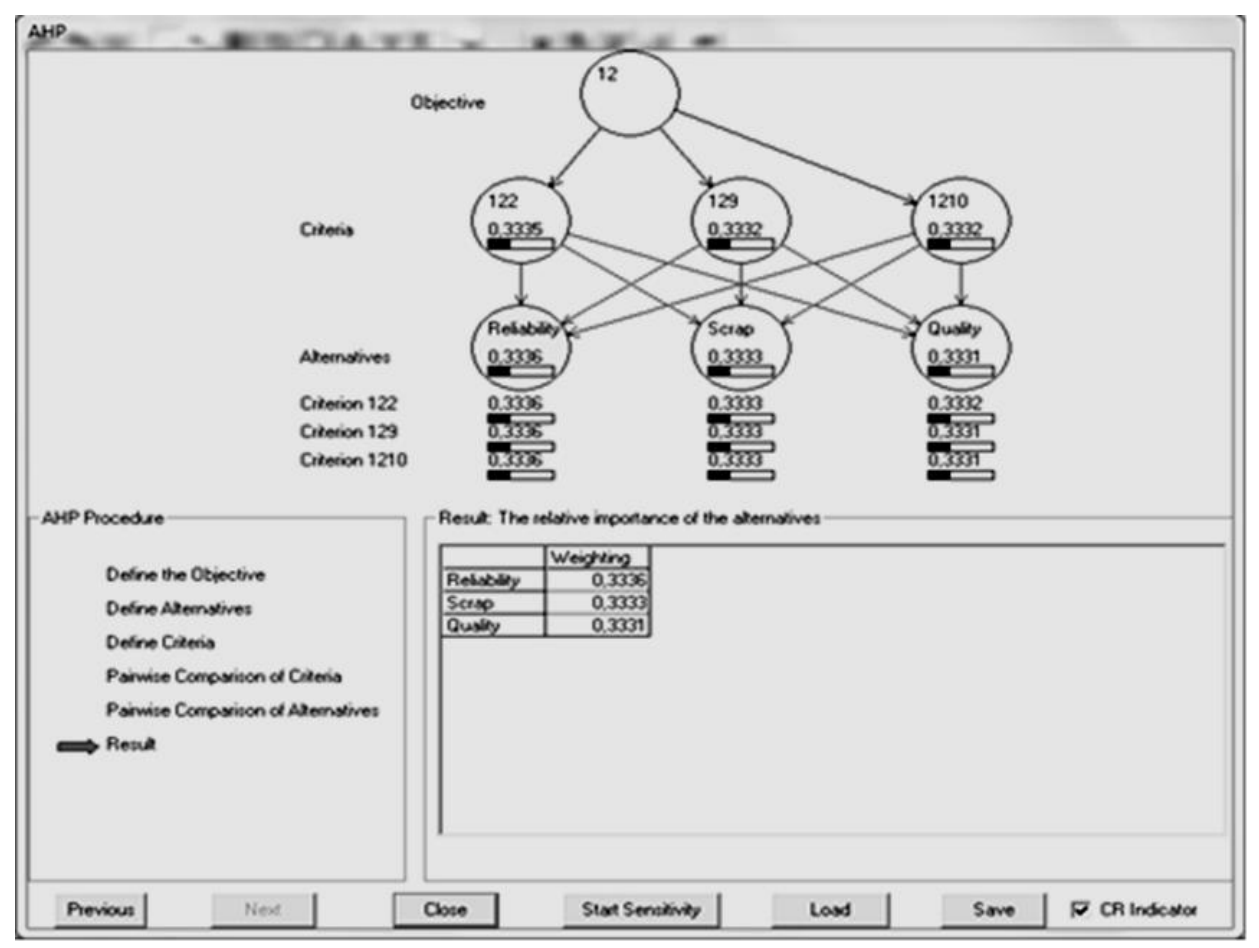

Figure 2. AHP Analysis as Example for the First Industrial Company

Objective: Logistics and Manufacturing (12)

Criteria: 122 - Scarp rate, 129 - Reliability of logistical support, 1210 - Mean times between failures

Criteria values: $122(4,5), 129(1,5), 1210(1,5)$

Alternatives: reliability, scrap, quality

The result shows that the most important alternative is Reliability, which has 0,0003 better result than Scrap, and 0,0005 better result than Quality.

Analysing the most important alternatives in defined four sectors by comparing the following results: Sector 11: 0,3334 Selling, Sector 12: 0,3336 Reliability, Sector 13: 0,3337 Income, Sector 14: 0,3334 Rights, the final result showed that the most important alternative is Income.

TAPS and AHP are usually used for analysing variables concerned only to production. The way this paper uses these methods is innovative because of using new KPIs which belong to different sectors and because of using calculations for analysing assessment of KPIs which were not used for these methods before.

\section{Non-Parametric Statistical Analysis}

Since the survey was conducted through interviews of General management about possibilities for organising effective and efficient production with minimum cost and Middle management as managers of functional areas to asses fifteen KPIs within each functional area, it opens opportunities for Non-parametric statistical analyses. The aim is to analyse assessment from general managers of international industrial companies for four defined functional areas and the average scores of KPIs of functional areas from sector managers.

In order to investigate the differences between the industrial companies, a Kruskal-Wallis test is conducted. This test is a non-parametric alternative to one-way ANOVA. It is used to compare three or more samples, and it tests the null hypothesis that the different samples in the comparison were drawn from the same distribution or from distributions with the same median. The interpretation is similar to that of one-way ANOVA, except that it is based on ranks rather than means (StatSoft, Inc. 2013).

Descriptive indicators - Median and Mean (average ranges) for these variables for eight industrial companies as a representative sample for this analysis (since the results obtained in the eight companies are suitable for this analysis), are shown in Table 3 since these results are needed for Kruskal-Wallis test, and a Kruskal-Wallis test results as differences between the industrial companies are presented in Table 4.

Descriptive Indicators for Eight Companies

\begin{tabular}{|c|c|c|c|c|c|c|}
\hline \multirow{2}{*}{ Company } & \multicolumn{3}{|c|}{ Assessment for functional area of general managers } & \multicolumn{3}{|c|}{ Average scores of indicators of functional area from sector managers } \\
\hline & $\mathbf{N}$ & Median & Mean Rank & $\mathbf{N}$ & Median & Mean Rank \\
\hline 1 & 4 & 2.5000 & 16.00 & 4 & 3.3350 & 12.25 \\
\hline 2 & 4 & 3.5000 & 23.88 & 4 & 3.6000 & 16.38 \\
\hline 3 & 4 & 2.5000 & 16.00 & 4 & 3.5000 & 17.13 \\
\hline 4 & 4 & 2.0000 & 11.25 & 4 & 3.7350 & 19.63 \\
\hline 5 & 4 & 3.5000 & 23.88 & 4 & 3.3000 & 14.25 \\
\hline 6 & 4 & 1.5000 & 9.00 & 4 & 3.7300 & 21.25 \\
\hline 7 & 4 & 1.0000 & 9.13 & 4 & 3.4350 & 14.25 \\
\hline 8 & 4 & 3.0000 & 22.88 & 4 & 3.5300 & 16.88 \\
\hline Total & 32 & 2.0000 & & 32 & 3.5650 & 12.25 \\
\hline
\end{tabular}


Bogdan Kuzmanovic, Zdravko Tesic, Ivana Tomic, Sonja Buncic, Milos Tomic, Mirjana Sujic Stamenic. Performance...

Results of Kruskal-Wallis Test: Differences between the Industrial Companies

\begin{tabular}{|c|c|c|}
\hline & Assessment for functional area of general managers & Average scores of indicators of functional area from sector managers \\
\hline Chi-Square & 14.074 & 2.788 \\
\hline df & 7 & 7 \\
\hline Asymp. Sig. & $\mathbf{. 0 5 0}$ & .904 \\
\hline
\end{tabular}

Results of Kruskal-Wallis test show that there are no differences between international industrial companies in Average scores of KPIs of functional areas from sector managers. Results of testing the differences between the industrial companies in the Assessment for functional areas of general managers are on the border of statistical significance. $\mathrm{P}$-value is a probability that result of a statistical test is obtained by chance and if p-value is $\leq 0.05$, it can be considered that the result is significant, so it can be concluded there is no significant difference between assessment of General and Middle management (Tomic et al., 2018).

\section{Findings}

The results obtained in this research include knowledge of the most influential performance indicators within each of the defined four main areas of activity within the international industrial companies on achievement defined objective. Based on the results regarding the impact of KPIs and analysis with the help of defined approaches and programs, the findings provide suggestions for strategic decisions and the analyses performed complement each other.
Defining the new model, functional areas and KPIs, there was created a new method for management decision support. Using this method, KPIs are analysed during a period of one year in international industrial company with measuring the importance and value of each KPI in four areas: effectiveness, efficiency, cost reduction and performance.

Middle management within each functional area evaluate KPIs according to the importance and value for all four areas for each month, according to which the program calculates and shows the diagram for each sector and overall industrial company. In this analysis, the sector of Logistics and Production with monitoring and measurement of KPIs within the sector will be presented. Based on the analysis of the assessment KPIs for twelve months, the program calculates and graphically displays the mean value of all KPIs within the sector. Figure 3 shows analysis for every KPI defined with example for KPI Quality of transport, chosen as a representative KPI which is significant because of different results for months. The results are obtained by survey since sector managers assessed all KPIs during one year and this KPI shows that its importance for company efficiency is always 10 , since other values and importance depend from different factors.

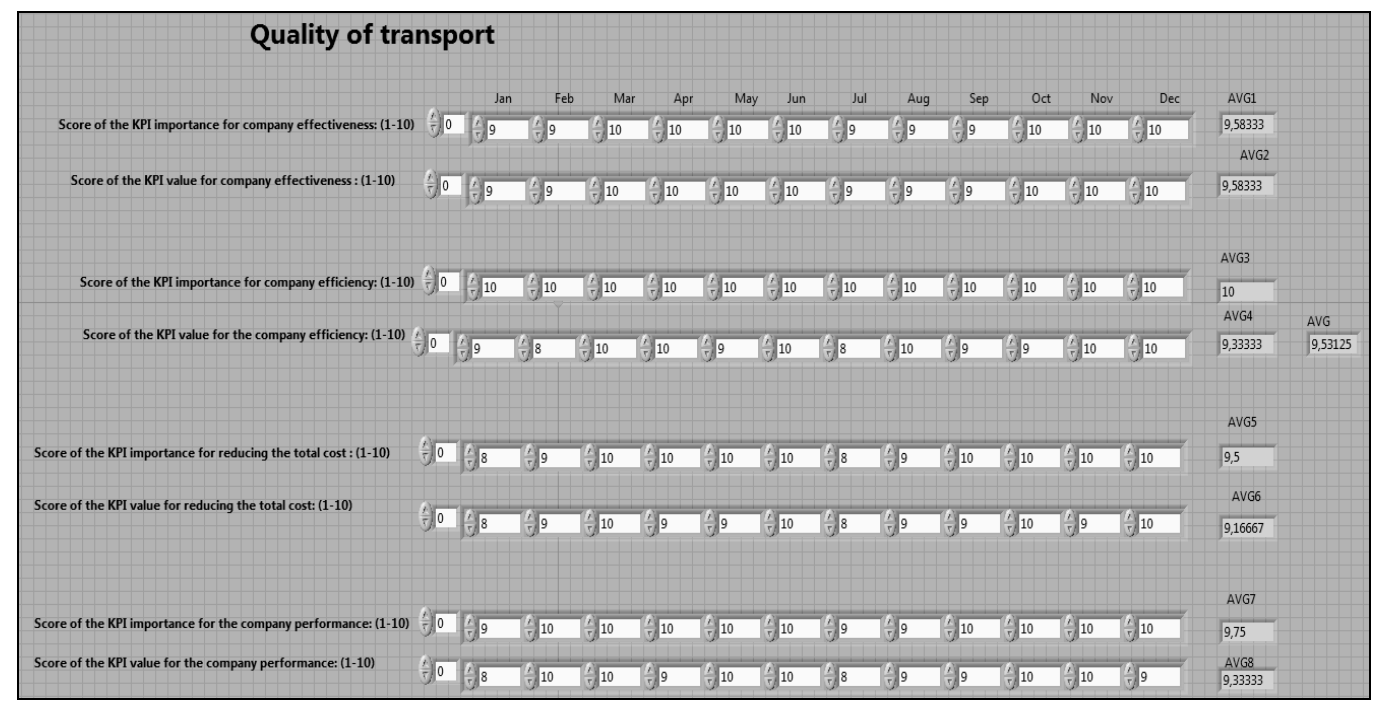

Figure 3. Analysis for Every KPI Defined

Figure 4 graphically displays the mean value score based on the average size for effectiveness, efficiency, reduce overall costs and performance of all KPIs in the sector for Logistics and Production. The greatest value, according to mean value score in the sector for Logistics and Production, is the value of KPIs is for reducing overall costs. Besides, the average value scores of effectiveness, efficiency and impact on performance also have high scores and management in this sector have to pay more attention on reducing the total cost, but also to analyze the other three areas.

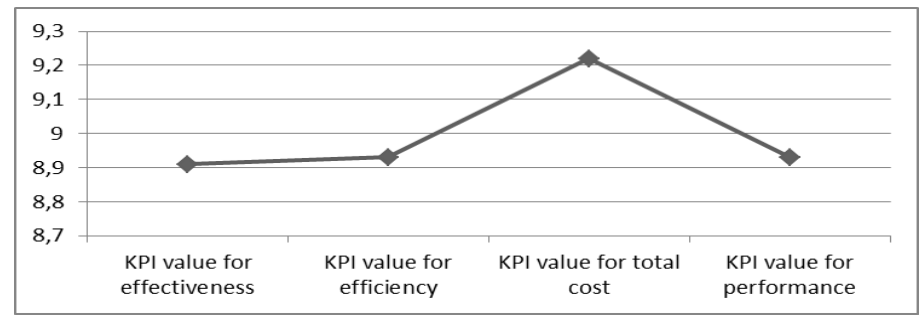

Figure 4. Graphical Display of Mean Value Score of KPIs in Sector of Logistics and Production 


\section{Contribution}

The expected results of the research can be applied in the field of management in analysing performance and making strategic decisions. Approaches and programs that were used for analysing KPIs have not been applied in a way that were applied in this study, and the new tool which is presented can be applied for creating strategies and performance analysis in the management of international industrial companies (Tomic et al., 2018).

Based on the analysis of the TAPS program in twenty international industrial companies, the largest impact on the defined objective - efficient production with minimum cost, has nine KPIs including six in the sector for Logistics and Production, and three from the sector for Human Resources. AHP analysis based on KPIs and defined alternatives produce a result that the most important alternative is Income since it mostly affects the defined goal. According to an analysis of the sector for Logistics and Production in Lab View, a result that was obtained from measurements KPIs during the twelve months the average value of KPIs shows that their greatest impact is on reducing overall costs.

Based on various measurement and analysis of KPIs within the above mentioned methods, it can be concluded that sector of Logistics and Production is the most influential sector for efficient operation with minimum cost, within the most important KPI is Low transport costs. In addition, sector for Human Resources also has a significant impact, as well as Income and Time from investment to cash collection.

\section{Conclusions}

In the first part of the research in the program TAPS it has been proved that overall efficiency of technological systems and low transport costs have the greatest impact on organization of efficient production with minimum costs. In AHP it has been proven that the most important alternative income. Using Non-parametric statistical analysis predictions of GM were tested and compared with results as average scores from Sector managers.

In the second part of the research a new method of Lab View software is created for analysing sixty KPIs previously defined. Using this method, KPIs are analysed in international industrial company during the year, with measuring the value and importance of each KPI in four areas: effectiveness, efficiency, cost reduction and performance of industrial companies. Managers of each functional area evaluated KPIs for each month assessing importance and value for all four areas, according to which the program calculated and displayed a chart for each sector, as well as for the total industrial company.

Based on the analysis of average values it can be concluded that in the field of Logistics and Production there is the greatest potential for changing business strategy. In addition, the average rating of the importance and value, efficiency and impact on performance in the other three areas have high marks and management in these sectors should also pay attention to the possibility of reducing the total cost.
Based on the research and different methods, the hypotheses are proven as follows:

Hypothesis 1: In the conducted research it has been proven that with concretization of the objective as Organizing effective and efficient production with minimum costs (with sixty KPIs defined which affect the set goal), it is possible to set goals in international industrial companies in a way that will ensure better management decisions. It has been also proven that a model for assessing quantities could be created with critical factors that influence on set goals based on which are designed models for making strategic decisions based on the evaluation of defined indicators. This research contains set goal, defined KPIs and measuring KPIs with different software and tools which gave result that the hypothesis is accepted with a high level of significance.

Hypothesis 2: The research has confirmed the assumption that measuring the output values according to defined and measured KPIs, input values and their relations can be determined and that can be applied in international industrial companies with the aim to provide better management decisions. The hypothesis is accepted with a high level of significance with all methods used in this research by analyzing KPIs and getting results useful for input values and business strategies.

Hypothesis 3: Creation of the new method in Lab View proves possibility for creating a software solution for analysing value and importance of KPIs on the cost reduction, efficiency, effectiveness and the performance during defined period of time with calculating mean values and creating graphs. Using the new method can be concluded that the reduction of total costs affects the overall performance of international industrial company which is proven by analysis in Lab View software, where result shows that the average of assessed values for the KPIs gives greatest value. The hypothesis is accepted with a high level of significance as the new method in Lab View software contains all defined elements and gave results useful for strategic management.

Based on the analysis of twenty international industrial companies in TAPS program, the biggest impact on a specific target, efficient production with minimum costs, have nine KPIs, including six in the field of Logistics and Production, and three in the sector of Human Resources. AHP analysis based on analysed KPIs and defined alternatives, gives a result that the most important alternative is Income because it has the greatest influence on a defined objective. According to the analysis in program Lab View, the results obtained from measuring KPIs during twelve months show they have the greatest impact on reducing the total cost.

The most important findings based on different methods for measuring and analysing KPIs within the above mentioned methods, give a conclusion that the sector Logistics and Production is the most influential sector for the efficient production with minimum costs, which include the most important KPI - Low transportation costs. In addition, the sector has a significant impact for human resources, as well as income from investments and time to payment of money. Besides that, sector for Human Resources also has a significant impact, as well as KPIs Income and Return on investment time. 
The research results can be applied in the field of management for performance analysing and making strategic decisions. Approaches and programs that were used for the analysis of KPIs have not been applied in a manner that was applied in this study, and a new tool that is presented can be used to create strategies and performance analysis for the management of international industrial companies which operate worldwide.
The research limitation of this paper is a sample of twenty companies since larger sample should give more results. Future areas of research should include sample of international industrial companies interviewing management from same companies in different countries and the results could be compared with the aim to give management better support for strategic decisions.

\section{References}

Aguinis, H., \& Pierce, C. A. (2008). Enhancing the relevance of organizational behavior by embracing performance management research. Journal of Organizational Behavior, 29, 139-145. https://doi.org/10.1002/job.493

Bourne, M., Mills, J., Wilcox, M., Neely, A., \& Platts, K. (2000). Designing, implementing and updating performance measurement systems. International Journal of Operations \& Production Management, 20(7), 754-771. https://doi.org/10.1108/01443570010330739

Burbidge, J. L. (1984a). A classification of production system variables. In: Hubner, H. (Ed.), IFIP Production Management Systems: Strategies and Tools for Design, Elsevier

Burbidge, J. L. (1984b). A Production System Variable Connectance Model. Cranfield Institute of Technology, England

Chaudhuri, K., Kumbhakar, S. C., \& Sundaram, L. (2016). Estimation of firm performance from a MIMIC model. European Journal of Operational Research, 255(1), 298-307. https://doi.org/10.1016/j.ejor.2016.05.005

De Lima, E. P., da Costa, S. E. G., \& de Faria, A. R. (2009). Taking operations strategy into practice: Developing a process for defining priorities and performance measures. Int. J. Production Economics, 122, $403-418$. https://doi.org/10.1016/j.ijpe.2009.06.022

De Toni, A., \& Tonchia, S. (2001). Performance Measurement Systems: Models, Characteristics and Measures. International Journal of Operations and Production Management, 21(1/2), 46-70. https://doi.org/10.1108/014 43570110358459

Epstein, M. J., \& McFarlan, F. W. (2011). Measuring the Efficiency and Effectiveness of a Nonprofit's Performance. Strategic Finance, 26-34.

Gunday, G., Ulusoy, G., Kilic, K., \& Alpkan, L. (2011). Effects of innovation types on firm performance. Int. J. Production Economics, 133, 662-676. https://doi.org/10.1016/j.ijpe.2011.05.014

Hammer, M., \& Champy, J. (1993). Reengineering the Corporation: A Manifesto for Business Revolution, London, UK: N.Brealey.

Hong, P., Doll, W. J., Revilla, E., \& Nahm, A. Y. (2011). Knowledge sharing and strategic fit in integrated product development projects: An empirical study. Int. J. Production Economics, 132, 186-196. https://doi.org/10.10 16/j.ijpe.2011.04.004

Hynuk, S., \& Benoit, R. (2010). Measuring Portfolio Strategic Performance Using Key Performance Indicators. Project Management Journal, Wiley Online Library, 41(5), 64-73.

Ittner, C. D., Larcker, D. F., \& Meyer, M. W. (2003a). Subjectivity and the Weighting of Performance Measures: Evidence from a Balanced Scorecard. The Accounting Review, 78(3), 725-758. https://doi.org/10.2308/ accr.2003.78.3.725

Ittner, C. D., Larcker, D. F., \& Randall, T. (2003b). Performance implications of strategic performance measurement in financial services firms. Accounting, Organizations and Society, 28(7-8), 715-741. https://doi.org/10.1016/S03613682(03)00033-3

Lohman, C., Fortuin, L., \& Wouters, M. (2004). Designing a performance measurement system: A case study. European Journal of Operational Research, 156(2), 267-286. https://doi.org/10.1016/S0377-2217(02)00918-9

Kaplan, R. S., \& Norton, D. P. (1992). The Balanced Scorecard - Measures that drive Performance. Harvard Business Review.

Kaplan, R., \& Norton, D. (1996). The Balanced Scorecard, Translating Strategy into Action, Boston, USA: HBS Press.

Kennerley, M., \& Neely, A. (2002). A framework of the factors affecting the evolution of performance measurement systems. International Journal of Operations and Production Management, 22(11), 1222-1245. https://doi.org/10.1108/01443570210450293

Koller, T., Goedhart, M., \& Wessels, D. (2005). Valuation: Measuring and Managing the Value of Companies, Fourth Edition, University Edition, John Wiley and Sons, Inc., ISBN 0-471-70218-8.

Koo, L. C., \& Koo, H. (2007). Holistic approach for diagnosing, prioritising, implementing and monitoring effective strategies through synergetic fusion of SWOT, Balanced Scorecard and QFD. World Review of Entrepreneurship, Management and Sust. Development, 3(1). https://doi.org/10.1504/WREMSD.2007.012131

Martinez, V., \& Kennerley, M. (2005). Performance Measurement Systems: Mix Effects, EURAM Conference, on-line proceedings, 4-7 May, Munich, Germany. 
Milosev, I., \& Tesic, Z. (2011). Investments in the Industry Field in the Emerging Markets, International Journal of Industrial Engineering and Management (IJIEM), 2, 4, 145-150, ISSN 2217-2661.

Muchiri, P., Pintelon, L., Gelders L., \& Martin, H. (2011). Development of maintenance function performance measurement. Framework and indicators. Int. J. Production Economics, 131, 295-302. https://doi.org/10.1016/ j.ijpe.2010.04.039

Neely, A. (2002). Business Performance Measurement: Theory and Practice, Cambridge University Press. https://doi.org/10.1017/CBO9780511753695

Neely, A., Mills, J., Platts, K., Richards, H., Gregory M., Bourne M., \& Kennerley, M. (2000). Performance measurement system design: developing and testing a process-based approach. International Journal of Operations \& Production Management, 20(10), 1119-1145. https://doi.org/10.1108/01443570010343708

Neely, A. D., Gregory, M. J., \& Platts, K. W. (2005). Performance measurement system design: a literature review and research agenda. International Journal of Operations and Production Management, 25(12), 1228-1263.

Parmenter, D. (2007). Key Performance Indicators: Developing, Implementing and Using Winning KPIs, New York, USA: John Wiley, ISBN: 978-1-118-92510-2.

Selden, S. C., \& Sowa, J. E. (2004). Testing a Multi-Dimensional Model of Organizational Performance: Prospects and Problems. Journal of Public Administration Research and Theory, 14(3), 395-416. https://doi.org/10.1093/ jopart/muh025

Spitzer, D. R. (2007). Transforming Performance Measurement, New York, USA: AMACOM.

Stainer, L. (2006). Performance Management and Corporate Social Responsibility: The Strategic Connection, Strategic Change, 15, 253-264. https://doi.org/10.1002/jsc.761

Tan, K. H., \& Platts, K. (2002). Managing Manufacturing Action Plans. International Journal of Innovation Management, 6(4), 369-385. https://doi.org/10.1142/S1363919602000677

Tan, K. H., \& Platts, K. (2004). Operationalising strategy: Mapping manufacturing variables. Int. J. Production Economics, 89, 379-393. https://doi.org/10.1016/S0925-5273(02)00377-8

Tesic, Z., Kuzmanovic, B., Tomic, M., \& Tomic, I. (2014). An innovative Performance Measurement and Management Method, 21. EurOMA Conference, Palermo: Universita Deglo Studi Di Palermo, 20-25 Jun, 2014.

Tesic, Z., Stevanov, B., Jovanovic, V., Tomic, M., \& Kafol, C. (2016). Period Batch Control - A Production Planning System Applied to Virtual Manufacturing Cells. Int. Journal of Simulation Modeling, 15, 2, $288-301$. https://doi.org/10.2507/IJSIMM15(2)8.337

Tomic, I., Tesic, Z., Kuzmanovic, B., \& Tomic, M. (2018). An empirical study of employee loyalty, service quality, cost reduction and company performance. Economic Research-Ekonomska Istrazivanja, 31(1), 827-846. https://doi.org/10.1080/1331677X.2018.1456346

Tsamenyi, M., Sahadev, S., \& Qiao, Z. S. (2011). The relationship between business strategy, management control systems and performance: Evidence from China. Advances in Accounting, incorporating Advances in International Accounting, 27(1), 193-203. https://doi.org/10.1016/j.adiac.2011.05.001

Ukko, J., Tenhunen, J., \& Rantanen, H. (2007). Performance measurement impacts on management and leadership: Perspectives of management and employees. International Journal of Production Economics, 110, 39-51. https://doi.org/10.1016/j.ijpe.2007.02.008

Vergidis, K., Turner, C. J., \& Tiwari, A. (2008). Business process perspectives: Theoretical developments vs. real-world practice. International Journal of Production Economics, 114, 91-104. https://doi.org/10.1016/j.ijpe.2007.12.009

StatSoft, Inc. (2013). Electronic Statistics Textbook. Tulsa, OK: StatSoft.

The article has been reviewed. Received in September 2016; accepted in February 2019. 